\title{
EXTRAPULMONARY MANIFESTATION OF SARCOIDOSIS ASSOCIATED WITH AUTOIMMUNE HEMOLYTIC ANEMIA (AIHA)
}

Iane Tamara Dondé1,^, Viviane Queiroz de Oliveira Maia', Danielly Dantas Pimentel', Gizelle Gouvea Rezende', Gustavo Roberto Lourenço', Juliana de Jesus Boscolo', Luciana Akita', Viviane Alves Costa', Taísa Morete da Silva'

1.Faculdade de Medicina de São José do Rio Preto, São José do Rio Preto (SP), Brazil.

*Corresponding author: ianetamara@hotmail.com

\section{BACKGROUND}

Sarcoidosis is a systemic disease that can involve all organ systems to a varying extent and degree. Most frequently involves the lung, but up to $30 \%$ of patients present extrapulmonary manifestations of sarcoidosis. The most common sites include the skin, heart, kidney, eyes, reticuloendothelial system, musculoskeletal system, exocrine glands and central nervous system. The association between sarcoidosis and AlHA is extremely rare, there are about 13 case reports in literature.

\section{CASE REPORT}

A 39-year-old man was admitted to the hospital with progressive weight loss of approximately 22 pounds in 6 months, asthenia and pancytopenia. His past medical history included type II diabetes mellitus, in regular use of metformin and glibenclamide, and anemia requiring blood transfusion in pre-surgical exams, a year before. Physical examination revealed splenomegaly, jaundice and pale mucous membranes. The initial complete blood count was remarkable for anemia (hemoglobin $7.5 \mathrm{~g} / \mathrm{dL}$ ), leukopenia (white blood cell count $2.3 \times 10^{9 / L}$ ) and thrombocytopenia (platelet count $118 \times 109 / \mathrm{L}$ ). Laboratory tests showed an RCP of $0.72 \mathrm{mg} / \mathrm{dL}$, indirect bilirubin: $5.6 \mathrm{mg} / \mathrm{dL}$, LDH of $530 \mathrm{UI} / \mathrm{L}$, coombs test was positive. Liver function and enzymes were within the normal levels and the renal function as well. Serum ionic calcium and alkaline phosphatase levels were respectively $1.26 \mathrm{mmol} / \mathrm{L}$ and $128 \mathrm{U} / \mathrm{L}$. Antinuclear antibodies were negative. In the thoracoabdominopelvic scan there were multiple mediastinal, hilar and abdominal adenopathies, hepatomegaly and marked splenomegaly $\left(1100 \mathrm{~cm}^{3}\right)$. Serology for hepatitis and HIV were negative. A bone marrow biopsy was performed showing a hypercellular bone marrow without monoclonal protein. The histopathological examination of the thoracic lymph node showed a non-caseous chronic granulomatous process. The patient was treated with high dose of prednisone $(1 \mathrm{mg} / \mathrm{kg} / \mathrm{day})$ during four weeks, followed by a slow tapering and was discharged after clinical improvement. In outpatient consultation methotrexate and folic acid were added.

\section{CONCLUSION}

Multiple autoimmune diseases have been reported in the literature in association with sarcoidosis, including a high frequency of endocrine autoimmunity, polyglandular autoimmune syndromes, idiopathic thrombocytopenic purpura, Sjogren's syndrome and connective tissue disease. We report a rare association of systemic sarcoidosis and idiopathic AlHA. It may be explained by the similar pathological basis involving Th1 and Th17 lymphocytes. There are no guidelines on how to treat sarcoidosis with AlHA. 